\title{
Towards a reefscape ecology: relating biomass and trophic structure of fish assemblages to habitat at Davies Reef, Australia
}

\author{
J. E. Arias-González ${ }^{1, *}$, T. J. Done ${ }^{2}$, C. A. Page ${ }^{2}$, A. J. Cheal' ${ }^{2}$, S. Kininmonth ${ }^{2}$, \\ J. R. Garza-Pérez ${ }^{1,3}$ \\ ${ }^{1}$ Laboratorio de Ecología de Ecosistemas de Arrecifes Coralinos, Departamento de Recursos del Mar, Centro de \\ Investigación y de Estudios Avanzados del Instituto Politécnico Nacional, Unidad Mérida, Antigua Carretera a \\ Progreso Km. 6, Mérida, Yucatán 97310, Mexico \\ ${ }^{2}$ Australian Institute of Marine Science, PMB \#3, Townsville MC, Queensland 4810, Australia \\ ${ }^{3}$ Rosenstiel School of Marine Science, 4600 Rickenbacker Cswy, Miami, Florida 33149, USA
}

\begin{abstract}
The complex relationship between coral reef fish assemblages and reef habitats at Davies Reef, a middle-shelf reef in the Great Barrier Reef, Australia, was approached from a reefscape perspective. A reefscape merges the spatial patterns found in a reef with 3 ecological components: structure, function and change. The main objective of this study was to explore the relationship between function (biomass and trophic structure of fish assemblages) and structure (reef habitat) within a reef. Three reef fish groups were defined using multi-dimensional scaling, and their similarity was evaluated using SIMPER analysis. From the benthic surveys conducted at the same sites we defined 3 reefscapes: A, 'encrusting non-Acropora', B, 'Acropora' and C, 'low density massive non-Acropora'. Reefscape A was characterised by maximum fish species richness and biomass, while maximum fish diversity was found in Reefscape B. Reefscape C had the minimum values of fish biomass. The relationship between fish groups (using biomass as a proxy) and habitat was explored using redundancy analysis, which was also used to identify significant fish species within each reefscape. The relationship between the trophic structure (guilds) and habitat was explored using the 4th corner analysis, and this analysis revealed that substratum types differed in terms of their utility as proxies for associated fish species and trophic guilds. The present study stresses the importance of within-reef variability as a determinant of composition and relative abundance of local reef fish assemblages. It also suggests that, while loss or change of habitat structure (i.e. coral cover or change in the dominant coral type) could reduce species richness and biomass, some of the habitat features to which fishes cue are probably coarser geomorphological and environmental zones.
\end{abstract}

KEY WORDS: Reef habitat - Biomass - Trophic structure - Coral reef fishes · Great Barrier Reef · Biodiversity · Complexity

\section{INTRODUCTION}

The term 'landscape' is used to describe any spatially heterogeneous terrestrial area in terms of characteristics of structure, function and change (Turner \& Gardner 1991). Here, 'structure' refers to the spatial relationships between distinctive habitats within the prescribed area, and 'function' refers to the interaction between spatial elements, notably the flow of energy, materials and organisms among the component habitats. 'Change' refers to alteration in the structure and function through time. The variability across 
and around large coral reefs may also be considered in similar terms. We use the term 'reefscape' to describe spatially discrete elements of morphological and biological structure of a coral reef to enable exploration of the complex relationships between the fixed physical structure (including benthic organisms such as corals) and its most conspicuous motile component, the reef fishes.

How well reef benthic composition, diversity, abundance and/or structural complexity might predict reef fish composition and diversity has been the focus of numerous studies (Risk 1972, Gladfelter \& Gladfelter 1978, Gladfelter et al. 1980, Carpenter et al. 1981, Roberts \& Ormond 1987). Heterogeneity and complexity in reef fish habitat, manifesting as local differences in food, shelter and mating sites (Caley et al. 2001), are important determinants of pattern and diversity in reef fish assemblages (Grigg 1994, McCormick 1994, Ault \& Johnson 1998, Nuñez-Lara \& Arias-González 1998, Jones \& McCormick 2002, Nuñez-Lara et al. 2005). Such local habitat characteristics can also set an upper limit on local fish population sizes, affect the magnitude of fish recruitment in space and time, and modify patterns of juvenile fish growth (reviewed in Jones \& McCormick 2002). Not surprisingly, not all habitat characteristics are equally important in influencing reef fish communities (Legendre et al. 1997, Jones \& Syms 1998).

'Coral reef habitat' is rarely defined explicitly, and often mixes geomorphology (e.g. crest, back reef, or spur and groove zone) and biotic cover (e.g. Porites spp., turf algae) and substrate irregularity (e.g. heterogeneity, complexity, rugosity). There is also little uniformity in the scales or use of habitat classification (Jones \& Syms 1998), which has led to confusion in interpretation (Mumby \& Harborne 1999) and does not allow easy direct comparisons of studies. Nor can it be assumed that fishes are responding to the same spatial units as perceived by human observers.

Increasingly, studies are separating benthic and geomorphic attributes in the development of coral reef habitat classifications (Chancerelle 1996, Phillips et al. 1997, González-Gándara et al. 1999, Mumby \& Harborne 1999). Habitats are defined exclusively according to ecological attributes (biotic cover), and the associated geomorphologic classes are then assigned to each habitat class. This is the approach adopted in the present study. We classified reef fish assemblages from a wide range of habitats within Davies Reef on the Great Barrier Reef (GBR) and looked for habitat characteristics that were associated with the attributes of each reef fish assemblage. In doing so we investigated the 2 reefscape characteristics: structure (habitat) and function (the biomass and trophic structure of fish assemblages that is sustained by that structure).

\section{MATERIALS AND METHODS}

Study area. Davies Reef $\left(18^{\circ} 50^{\prime} \mathrm{S}, 47^{\circ} 39^{\prime} \mathrm{E}_{\text {; Fig. }} 1\right)$ is a mid-shelf reef located in the central section of the GBR (Done 1982, Riddle et al. 1990). Mid-shelf reefs in this section of the GBR are located 50 to $80 \mathrm{~km}$ from the coast. Davies Reef has a typical geomorphologic profile for reefs on the GBR: slope, crest, reef flat and lagoon with patch reefs (or 'bommies'), and has a steeply sloping reef front dropping to depths of ca. $50 \mathrm{~m}$ (Bradbury et al. 1986). Behind the reef front is an extensive lagoon (6 to $15 \mathrm{~m}$ depth), which comprises approximately $50 \%$ of the reef's area, largely open to the west and bounded to the southeast by a $300 \mathrm{~m}$ wide intertidal reef flat. The outer reef slope is gradual in the windward sector (SW/S/SE sectors) and steep in the more sheltered sector (SW/N/SE). Inside the lagoon there is a complex maze of reef structures, including a conspicuous shelf of sand with intertidal reef patches. The prevailing winds and associated waves in this region are from the southeast (Riddle et al. 1990).

Sampling. We surveyed benthos and fishes from 7 to 12 May 2002, using 54 fish and video sampling stations (Fig. 1). Sites were selected from an aerial photograph (1:5000) to maximise the range of habitats surveyed (reef slopes, shelves and submerged patch reefs). Fish and benthos were censused using transects laid at depths we believed would best characterise habitat features used by fishes, viz. towards the mid-range depth of the sides of bommies (1 to $10 \mathrm{~m}$ depth), the reef slope (1 to $8 \mathrm{~m}$ depth), or submerged shelf areas (1 to $6 \mathrm{~m}$ depth) and also in the shallower parts of these areas (typically $<1 \mathrm{~m}$ ). At each station, fish were visually censused either by snorkelling (for sites less than $\sim 2 \mathrm{~m}$ ) or by SCUBA (greater than $\sim 2 \mathrm{~m}$ ). First, a transect line was positioned along the chosen depth contour, and then 2 passes were made, the first recording large mobile reef fishes, and the second, small and juvenile fishes. All fishes were categorised by species and length classes. Large fish (>10 cm length) were categorised into $10 \mathrm{~cm}$ categories, while small and juvenile fishes ( $\leq 10 \mathrm{~cm}$ length) were categorized as $<2$ or $2-10 \mathrm{~cm}$.

We converted fish lengths to biomass ( $g$ wet weight $\mathrm{m}^{-2}$ ) using the allometric equation $W=a L^{b}$. The constants for each species were obtained from FishBase (www.fishbase.org/home.htm) or, if the species in question was not logged in FishBase, from a species with a similar shape. For each species, total biomass per census was estimated as the average weight multiplied by the abundance.

The benthic community at each site was surveyed using an underwater video camera to record a $40 \mathrm{~cm}$ wide swathe along each $50 \mathrm{~m}$ transect. The camera was held approximately $50 \mathrm{~cm}$ to the side of the tape 
and approximately normal to the substrate. Each video transect was then sampled using 200 systematically dispersed points (Page et al. 2001). The benthos under each point sampled was identified to the lowest taxonomic group and life form possible. For some analyses, data were grouped into the following major benthic categories: hard coral, soft coral, coralline algae, macro-algae, turf algae, sponge and other benthos. A combination of morphology and taxonomic grouping was considered the most appropriate for the purposes of this study, with the assumption that reef fish communities, overall, are more likely to be associated with coral growth forms than with particular coral species.

Classification of fish assemblages and habitats. Fish transect information was compiled into a matrix (species biomass by transect) and used to compute Bray-Curtis similarity among all transects. We used non-metric, multi-dimensional scaling analysis (MDS; Clark 1993) on transformed square root fish species biomass to generate groups of fish assemblages. We then conducted a non-metric, 1-way, pairwise analysis of similarity (ANOSIM; Clark \& Warwick 1994) among the groups, and a SIMPER analysis (Clark \& Warwick 1994) to determine which species contributed most to the similarities and differences among the fish assemblages. We then characterised each fish assemblage using: biomass and trophic structure. For biomass, we used redundancy analysis (RDA) and Monte Carlo permutation tests (Program CANOCO, Ter Braak \& Smilaur 1998) on Hellinger transformation of the fish species biomass data. Legendre \& Gallagher (2001) have shown that this transformation makes species abundance data amenable to analyses like principal component analysis (PCA) or RDA. We performed an RDA analysis for 3 fish assemblages against habitat characteristics, and to examine fish trophic structure we used 4th corner analysis (Legendre et al. 1997). This latter technique detects associations between trophic structure and habitat, as well as testing their significance using permutations. In our case, the 2 underlying assumptions for the tests are: (1) that all fish species are found at locations where they encounter appropriate living conditions; and (2) that they do so independently of each another (Model I in Legendre et al. 1997). We allo- cated each fish species to 1 of 6 trophic categories: 1 = fish feeders $(F), 2=$ macro-invertebrate feeders $(\mathrm{Ma})$, 3 = micro-invertebrate feeders (Mi), 4 = zooplankton feeders (Z), 5 = macro-algal feeders (H1), 6 = micro-algal feeders (H2) and $7=$ coral feeders (C). Species were assigned to these categories based on data obtained from Kulbicki et al. (1994).

\section{RESULTS}

A total of 206 species of reef fishes (202 identified and 4 unidentified) were recorded in the 54 transects surveyed at Davies Reef. The most common families
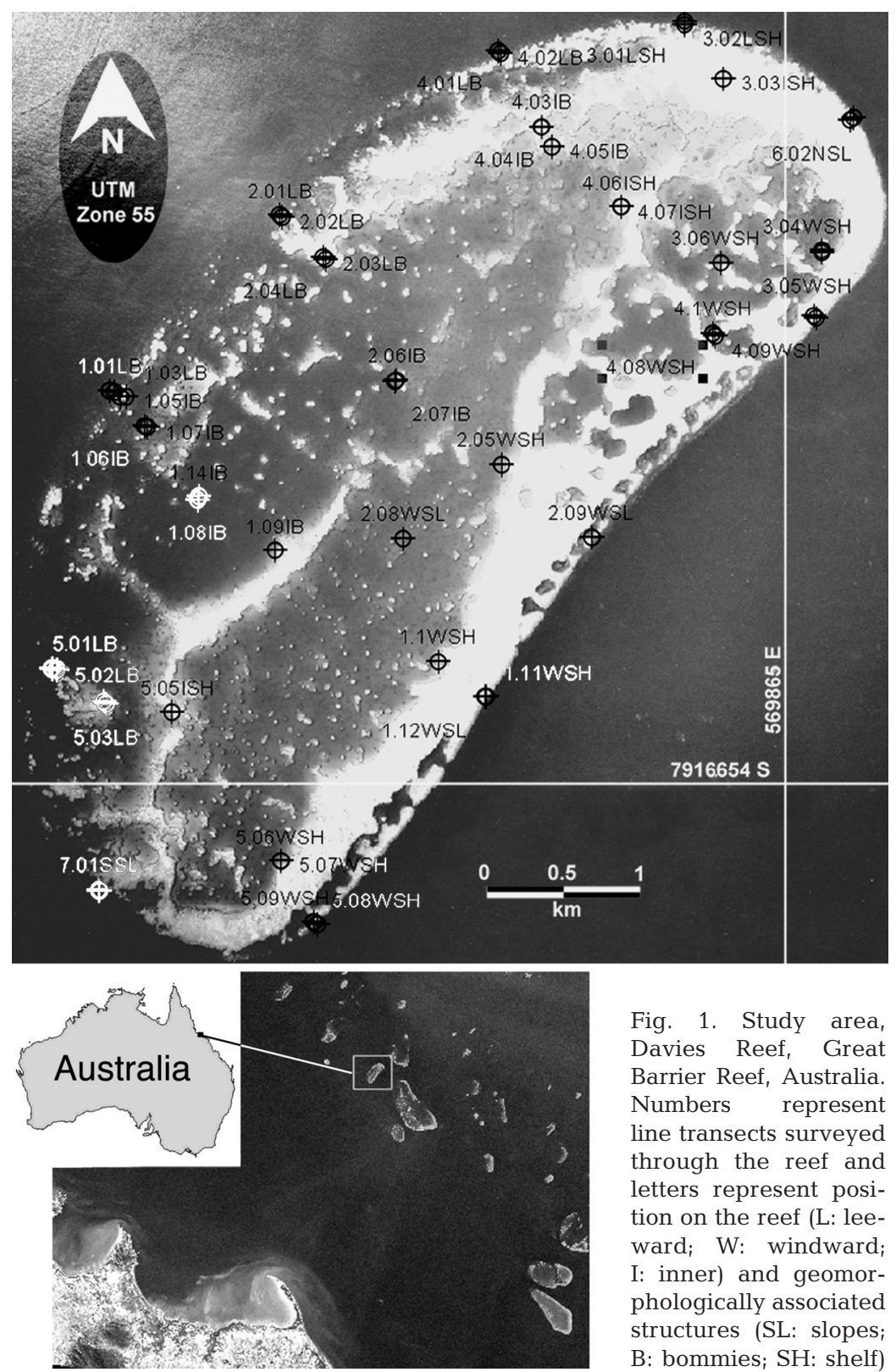

Fig. 1. Study area, Davies Reef, Great Barrier Reef, Australia. Numbers represent line transects surveyed through the reef and letters represent position on the reef (L: leeward; W: windward; I: inner) and geomorphologically associated structures (SL: slopes; B: bommies; $\mathrm{SH}$ : shelf) 
were the Pomacentridae, Labridae, Chaetodonthidae, Acanthuridae, Scaridae and Serranidae. Fish biomass $\mathrm{m}^{2}$ averaged $( \pm \mathrm{SE}) 246 \pm 18 \mathrm{~g}$ wet weight $\mathrm{m}^{-2}$, and fish abundance averaged $( \pm \mathrm{SE}) 37 \pm 0.99$ fishes $\mathrm{m}^{-2}$. Species incidence was extremely patchy across transects, with the majority of species represented in only a few transects, in fact more than half of all species occurred in $<5$ transects. No species were represented in all 54 transects, and only 20 species occurred in more than half of all transects. Forty-eight species (24\%) were present in only 1 transect; 22 species, in 2 (11\%); and 12 , in $3(6 \%)$. Most species were also rare and had extremely low biomasses $\mathrm{m}^{-2}\left(<1 \mathrm{~g} \mathrm{~m}^{-2}\right)$. The average biomass of even the most dominant species (the small damselfish Neopomacentrus azysron) was still low, at only $24 \mathrm{~g} \mathrm{~m}^{-2}$. The 5 most important species, in terms of their frequency and biomass, belonged to the family
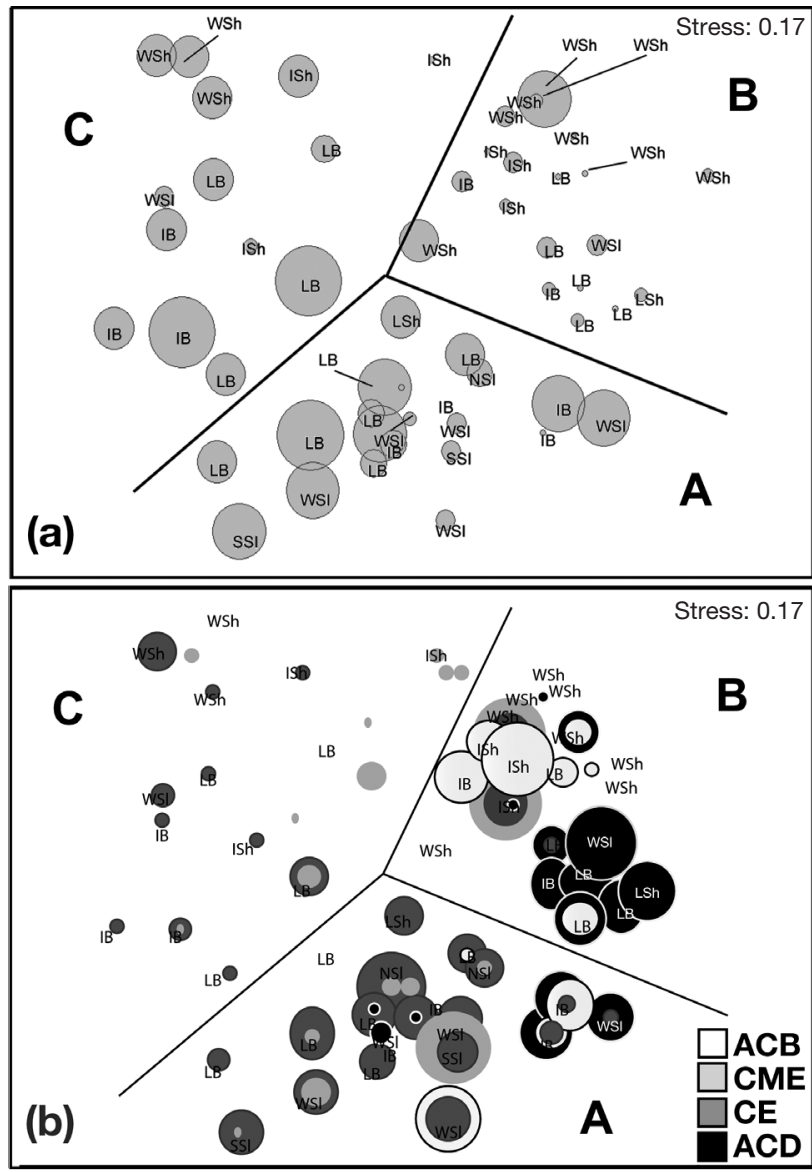

Fig. 2. Multi-dimensional scaling (MDS) ordination of the 54 transects, based on fish species biomass (measured by Bray-Curtis similarity coefficient). Reefscapes A, B and C labelled. (a) Symbol sizes represent maximum depth of each transect (larger symbols being deeper). (b) Symbol sizes represent percentage morphotypes cover in each transect (CE: coral, encrusting [non-Acropora]; CME: coral, Millepora encrusting; ACB: branching Acropora; ACD: digitate Acropora)
Pomacentridae (Pomacentrus lepidogenys, Neopomacentrus azysron, Pomacentrus moluccensis, Acanthochromis polyacanthus and Pomacentrus bankanensis).

The MDA analysis (Fig. 2) suggested that the fish species at Davies Reef can be split into 3 main assemblages or groups. These groups, while overlapping in their species composition (Table 1), do segregate to some extent according to depth (Fig. 2a) and total coral cover (Fig. 2b; intergroup differences significant at $\mathrm{p}<0.05$ in ANOSIM analysis), but also the cover of specific coral groupings. For convenience, we labelled each reefscape after prominent benthic features: A, 'encrusting non-Acropora', B, 'Acropora' and C, 'low density massive non-Acropora'.

An independent hierarchical cluster analysis using the fish data only (Fig. 3) produced essentially the same site groupings as the MDA analysis. In both methods, shelves (Sh), bommies (B) and slopes (Sl) had a tendency to cluster together, with patterns that also appeared to relate to reef aspect. For example, Cluster A contained mainly transects from the slope and bommie sites (6 m average depth, $10 \mathrm{~m}$ maximum depth). Cluster B contained mainly shelf transects, with only a few bommie and slope sites (2 $\mathrm{m}$ average depth). Cluster $\mathrm{C}$ included bommie, shelf and slope sites (4 m average depth).

\section{Cluster A: The encrusting non-Acropora reefscape and associated fishes}

This reefscape is dominated by encrusting nonAcropora corals (typically $>20 \%$ cover; Fig. 4), with Acropora and soft corals typically occupying $<7$ and $3 \%$ of the benthos, respectively, and with low coverage of zoanthids and sponges (typically $<2$ and $1 \%$, respectively). The reefscape is relatively free of sand, and with relatively low coverage of turf algae (mean coverage $<37 \%$ ) and moderate coverage of calcareous and other algae (14 and 12\%, respectively) compared to the other reefscapes.

Fish biomass averaged $( \pm \mathrm{SE}) 322 \pm 37 \mathrm{~g}$ wet weight $\mathrm{m}^{-2}$ (Fig. 4), while a total of 134 and an average of 40 species per transect were recorded. Pomacentrids were the dominant family, in terms of mean $( \pm \mathrm{SE})$ biomass and species richness (161 $\pm 22 \mathrm{~g}$ wet weight $\mathrm{m}^{-2}$ and $13 \pm 0.90$ species, respectively; Fig. 5a, b). Species from the genera Labridae, Scaridae, Chaetodonthidae and Acanthuridae were also conspicuous. Pomacentrus lepidogenys and Neopomacentrus azysron are diagnostic fish species of this reefscape (35.56 and $12.21 \%$ contributions to within-group similarities in SIMPER analyses), while Pterocaesio marri (3.90\% of within-group similarities), Pomacentrus brachialis (3.33\% of within-group similarities) and Ctenochaetus 
striatus $(3.27 \%$ of within-group similarities) are also notable species (Table 1, Cluster A). A total of 32 species contributed to $90 \%$ of within-group similarities within this reefscape.

Within each reefscape, subsets of substratum types were associated with distinctive subsets of fish species. For the fish assemblage overall, Monte Carlo permutation test revealed 2 significantly correlated benthic variables (Table 2): the highest biomass values of both Pomacentrus lepidogenys and Neopomacenrus azysron were associated with encrusting non-Acropora (CE) and Millepora (CME), whereas the highest biomass value of Pterocaesio marri was associated with branching non-Acropora (CB) and zoanthid (ZO) (Fig. 6a). Fish families in Reefscape A did not partition themselves across 3 growth forms of Acropora (table, encrusting and branching), although different species within those families did. For example, Pomacentrus bankanensis, Thalassoma hardwicke, Thalassoma amblycephalum and Scarus globiceps were consistently partitioned across coralline algae (CA), Halimeda (HA), sub-massive non-Acropora (CS) and tabulate Acropora (ACT), while Neopomacenrus azysron, Pomacentrus lepidogenys, Abudefduf whitleyi and Scarus niger were consistently partitioned across encrusting nonAcropora (CE) and Millepora (CME).

In terms of trophic groups, zooplankton feeders were by far the most dominant trophic category in Reefscape A (mean \pm SE biomass per transect: $240.75 \pm 34.69 \mathrm{~g}$ wet weight $\mathrm{m}^{-2}$; Figs. 4 \& 7). Plant and micro-invertebrate feeders also made significant contributions to biomass $\left(\right.$ mean \pm SE: $40.6 \pm 5.05$ and $15.2 \pm 1.75 \mathrm{~g}$ wet weight $\mathrm{m}^{-2}$,

Table 1. Species causing intra-group similarities (70\% cum.) and inter-group dissimilarities (50\% cum.) based on Bray-Curtis similarity and dissimilarity in Reefscapes A, B and C. Species are ordered in decreasing percent contribution (Contrib.)

\begin{tabular}{|c|c|c|c|c|c|}
\hline Species & Contrib. \% & Cum.\% & Species & Contrib. \% & Cum. \% \\
\hline \multicolumn{3}{|c|}{$\begin{array}{c}\text { Cluster A } \\
\text { Average similarity }=31.35\end{array}$} & \multicolumn{3}{|c|}{$\begin{array}{l}\text { Clusters A \& B } \\
\text { Average dissimilarity }=85.15\end{array}$} \\
\hline Pomacentrus lepidogenys & 35.56 & 35.56 & Pomacentrus lepidogenys & 12.87 & 12.87 \\
\hline Neopomacentrus azysron & 12.21 & 47.77 & Neopomacentrus azysron & 10.72 & 23.59 \\
\hline Pterocaesio marri & 3.90 & 51.67 & Pomacentrus bankanensis & 4.54 & 28.13 \\
\hline Pomacentrus brachialis & 3.33 & 55.00 & Pterocaesio marri & 4.48 & 32.61 \\
\hline Ctenochaetus striatus & 3.27 & 58.27 & Cirrhilabrus punctatus & 3.93 & 36.54 \\
\hline Thalassoma lunare & 3.09 & 61.35 & Pomacentrus chrysurus & 3.91 & 40.45 \\
\hline Scarus niger & 2.95 & 64.30 & Chromis agilis & 3.81 & 44.26 \\
\hline Pomacentrus moluccensis & 2.91 & 67.22 & Acanthochromis polyacanthus & 3.71 & 47.97 \\
\hline Pomacentrus philippinus & 2.62 & 69.84 & Pomacentrus moluccensis & 3.27 & 51.24 \\
\hline \multicolumn{3}{|c|}{$\begin{array}{c}\text { Cluster B } \\
\text { Average similarity }=33.05\end{array}$} & \multicolumn{3}{|c|}{$\begin{array}{c}\text { Clusters B \& C } \\
\text { Average dissimilarity }=87.20\end{array}$} \\
\hline Pomacentrus chrysurus & 12.70 & 12.70 & Pomacentrus moluccensis & 6.36 & 6.36 \\
\hline Pomacentrus bankanensis & 9.77 & 22.47 & Chrysiptera rollandi & 5.78 & 12.13 \\
\hline Pomacentrus wardi & 6.95 & 29.42 & Pomacentrus bankanensis & 5.24 & 17.38 \\
\hline Acanthochromis polyacanthus & 6.16 & 35.58 & Pomacentrus chrysurus & 4.86 & 22.24 \\
\hline Pomacentrus moluccensis & 6.06 & 41.64 & Acanthochromis polyacanthus & 4.46 & 26.69 \\
\hline Chlorurus sordidus & 5.95 & 47.60 & Chromis agilis & 4.26 & 30.95 \\
\hline Thalassoma lunare & 4.57 & 52.17 & Cheilodipterus quinquelineatus & 4.06 & 35.00 \\
\hline Thalassoma hardwicke & 4.38 & 56.54 & Pomacentrus brachialis & 3.27 & 38.27 \\
\hline Chromis agilis & 4.26 & 60.80 & Assesssor macneili & 2.72 & 43.97 \\
\hline Halichoeres melanurus & 3.60 & 64.40 & Neopomacentrus azysron & 2.26 & 46.23 \\
\hline Scarus rivulatus & 3.56 & 67.96 & Pomacentrus wardi & 2.14 & 48.37 \\
\hline Dischistodus pseudochrysopoecilus & IS 3.05 & 71.02 & Cirrhilabrus punctatus & 2.12 & 50.49 \\
\hline \multicolumn{3}{|c|}{$\begin{array}{c}\text { Cluster C } \\
\text { Average similarity }=28.49\end{array}$} & \multicolumn{3}{|c|}{$\begin{array}{c}\text { Clusters A \& C } \\
\text { Average dissimilarity }=84.57\end{array}$} \\
\hline Chrysiptera rollandi & 25.01 & 25.01 & Pomacentrus lepidogenys & 13.54 & 13.54 \\
\hline Pomacentrus moluccensis & 20.06 & 45.07 & Neopomacentrus azysron & 11.15 & 24.69 \\
\hline Assesssor macneili & 6.68 & 51.75 & Pomacentrus moluccensis & 5.09 & 29.79 \\
\hline Pomacentrus brachialis & 4.91 & 56.66 & Cirrhilabrus punctatus & 5.04 & 34.82 \\
\hline Cheilodipterus quinquelineatus & 3.44 & 60.11 & Pterocaesio marri & 4.85 & 39.67 \\
\hline Choerodon fasciatus & 3.03 & 63.14 & Chrysiptera rollandi & 4.55 & 44.23 \\
\hline Amblygobius decussatus & 2.46 & 65.60 & Cheilodipterus quinquelineatus & 3.68 & 47.91 \\
\hline Caesio cuning & 2.45 & 68.05 & Pomacentrus brachialis & 3.48 & 51.39 \\
\hline Pomacentrus amboinensis & 2.30 & 70.35 & Caesio cuning & 2.66 & 54.05 \\
\hline
\end{tabular}




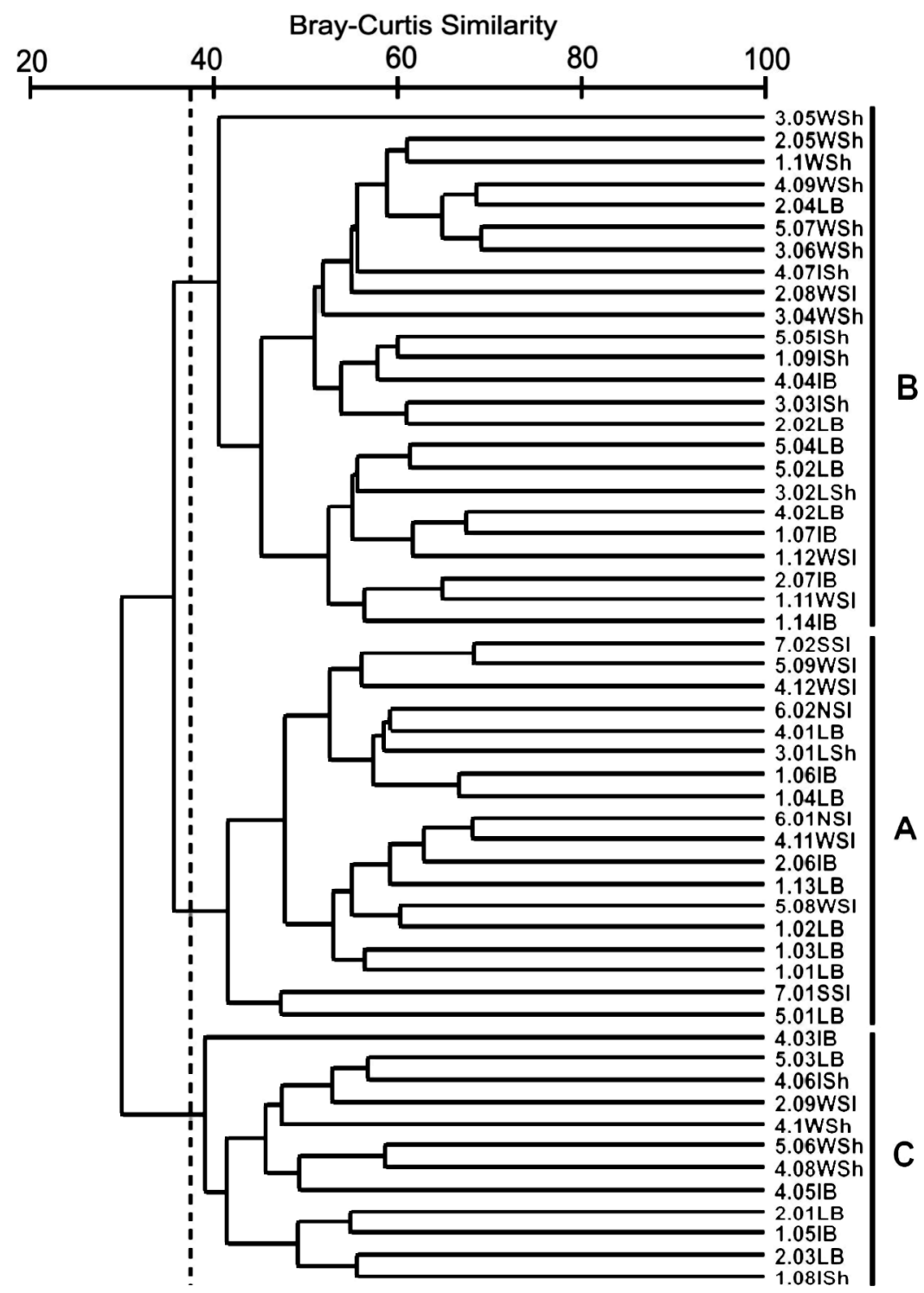

Fig. 3. Cluster analysis of the 54 transects, based on fish species biomass using Bray-Curtis similarity. Reefscapes A, B, and C labelled. Letters in cluster names represent geomorphologically associated structures (Sl: slopes; B: bommies; Sh: shelf) and position on the reef (L: leeward; W: windward; I: inner)

added 3D complexities to a substratum with patchy sand (12\%) and relatively high cover of turf algae (62\%). The cover of soft corals, sponges and other invertebrates was very low $(<0.40,0.09$ and $0.20 \%$, respectively). Fish biomass averaged $( \pm \mathrm{SE}) 201 \pm 17 \mathrm{~g}$ wet weight $\mathrm{m}^{-2}$ (Fig. 4), while 118 fish species were recorded with a mean of 36 species per transect. As in Reefscape A, Pomacentrids were again the dominant family in terms of biomass $(161 \pm 22 \mathrm{~g}$ wet weight $\mathrm{m}^{-2}$; Fig. 5a), whereas the Labridae contributed the highest number of species per transect (12; Fig. 5b). Pomacentrus chrysurus and $P$. bankanensis are distinguishing species in the sense that they made the highest contributions to within-group similarities (12.70 and $9.77 \%$, respectively). Also contributing significantly were $P$. wardi $(6.95 \%)$, Acanthochromis polyacanthus (6.16\%) and P. moluccensis (6.06\%) (Table 1). A total of 25 species made up $90 \%$ of within-group similarities. For the fish assemblage overall, Monte Carlo permutation test revealed 3 significantly correlated benthic variables (Table 2): the highest biomass of $P$. chrysurus was associated with digitate Acropora (ACD); the highest biomass of $P$. bankanensis was associated with sub-massive Acropora (ACS); and the highest biomass of $P$. wardi was associated with branching non-Acropora (CB), macroalgae (MA) and sponges (SP) (Fig. 6b).

Within-reefscape fish variability was associated with within-reefscape benthic variability (Fig. 6b). For example, the middle right of Reefscape B (Fig. 6b) was characterised by a variety of Acropora growth forms (Table 3), and a

respectively). There were 5 significant relationships between fish feeding categories and individual benthic attributes (Table 3). These were: macro-algal feeders negatively correlated to 'algae, other', 'zoanthids' and 'macro-algae'; macro-algal feeders positively correlated to encrusting Acropora; and micro-algal feeders negatively correlated to encrusting non-Acropora.

\section{Cluster B: Acropora reefscape and associated fishes}

In Reefscape B, the cover of Acropora corals was the highest of the 3 reefscapes (9\%; Fig. 4). The Acropora distinctive suite of Pomacentrids, Labrids and Scarids, the latter with individual species strongly associated with either coralline or turf algae. Other associations are observable in Fig. 6 b.

In terms of trophic function, plant feeders, zooplankton feeders and micro-invertebrate feeders made the highest contribution to the mean $( \pm \mathrm{SE})$ biomass of Reefscape B $(84.81 \pm 9.34,59.1 \pm 12.42$ and $29.8 \pm 2.32 \mathrm{~g}$ wet weight $\mathrm{m}^{-2}$ per transect, respectively) (Figs. 4 \& 7). Reefscape B had the highest plant-feeder biomass of all 3 seascapes. Table 3 presents the correlations of feeding habits and reef benthic categories. Holm's procedure detected 7 significant relationships, in none of which the cause and 


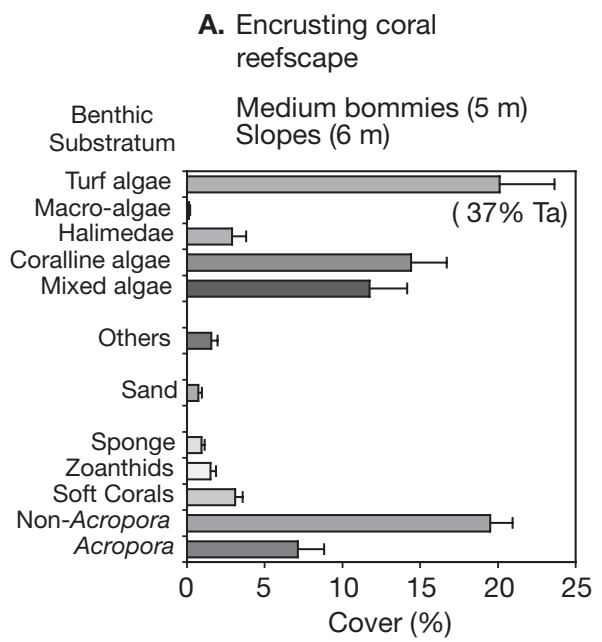

Fish

\begin{tabular}{|c|c|}
\hline $\begin{array}{l}\text { biomass } \\
\text { No. of species } \\
\text { Diversity } H^{\prime}\end{array}$ & $\begin{array}{l}322 \mathrm{~g} \mathrm{~m}^{-2} \\
134 \text { species } \\
40 \text { species/transect } \\
2.60 \text { bits }\end{array}$ \\
\hline $\begin{array}{l}\text { Distinguishing } \\
\text { species }\end{array}$ & $\begin{array}{l}\text { Pomacentrus lepidogenys } \\
\text { Neopomacentrus azysron }\end{array}$ \\
\hline $\begin{array}{l}\text { Main trophic } \\
\text { groups }\left(\mathrm{g} \mathrm{m}^{-2}\right)\end{array}$ & $\begin{array}{l}\text { Zooplankton feeders }(240) \\
\text { Plant feeders }(41) \\
\text { Micro-invertebrate feeders (15) }\end{array}$ \\
\hline
\end{tabular}

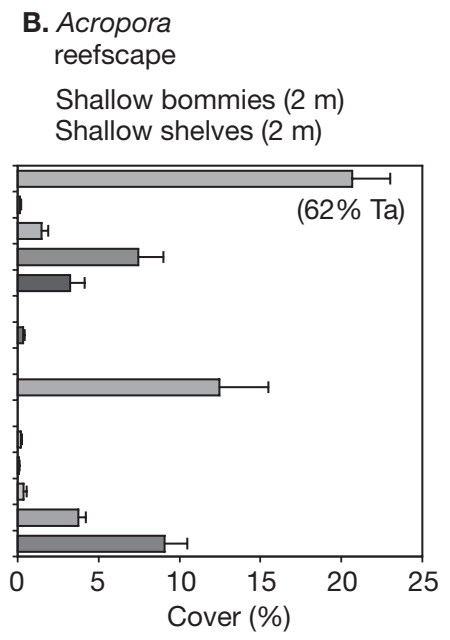

$201 \mathrm{~g} \mathrm{~m}^{-2}$

118 species

36 species/transect 2.90 bits

\section{Low coral reefscape}

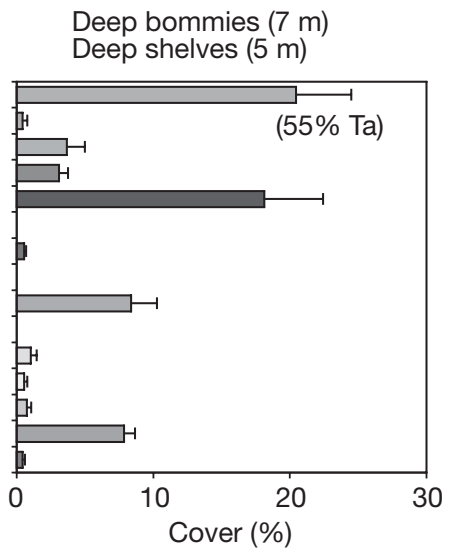

$199 \mathrm{~g} \mathrm{~m}^{-2}$

119 species

33 species/transect

2.71 bits

\section{Chrysiptera rollandi}

Pomacentrus bankanensis

Pomacentrus moluccensis

Plant feeders (85)

Micro-invertebrate feeders (59)

Zooplankton feeders (30)
Zooplankton feeders (99)

Plant feeders (26)

Micro-invertebrate feeders (27)

Macro-invertebrate feeders (24)

Fig. 4. Principal benthic substratum, fish characteristics (biomass, number of species, trophic groups) and dominant species associated with Reefscapes A, B and C (Ta: turf algae)

Table 2. Monte Carlo permutation test of the effect of environmental variables on fish species in Reefscapes A, B and C: branching Acropora (ACB), digitate Acropora (ACD), encrusting Acropora (ACE), sub-massive Acropora (ACS), tabulate Acropora $(\mathrm{ACT})$, bottlebrush Acropora (ACX), other algae (AO), coralline algae (CA), branching non-Acropora (CB), encrusting nonAcropora (CE), foliose non-Acropora (CF), Millepora (CME), massive non-Acropora (CM), sub-massive non-Acropora (CS), Halimeda (HA), macro-algae (MA), other (OT), sand (S), soft corals (SC), sponge (SP), turf algae (TA), zoanthids (ZO), unknown (UNK)

\begin{tabular}{|c|c|c|c|c|c|c|c|c|}
\hline \multicolumn{3}{|c|}{- Reefscape A- } & \multicolumn{3}{|c|}{ - Reefscape B } & \multirow[b]{2}{*}{ Variable } & \multirow{2}{*}{$\begin{array}{c}- \text { Reefscape C } \\
\lambda\end{array}$} & \multirow[b]{2}{*}{$\mathrm{p}$} \\
\hline Variable & $\lambda$ & $\mathrm{p}$ & Variable & $\lambda$ & $\mathrm{p}$ & & & \\
\hline $\mathrm{CE}$ & 0.09 & 0.014 & $\mathrm{ACD}$ & 0.14 & 0.006 & SP & 0.13 & 0.109 \\
\hline CME & 0.13 & 0.023 & $\mathrm{AO}$ & 0.09 & 0.016 & HA & 0.09 & 0.292 \\
\hline $\mathrm{AO}$ & 0.08 & 0.059 & $\mathrm{ACB}$ & 0.10 & 0.027 & TA & 0.09 & 0.349 \\
\hline $\mathrm{CF}$ & 0.07 & 0.083 & MA & 0.07 & 0.057 & $\mathrm{CE}$ & 0.09 & 0.380 \\
\hline $\mathrm{ACT}$ & 0.06 & 0.171 & $\mathrm{CM}$ & 0.06 & 0.098 & $\mathrm{SC}$ & 0.08 & 0.391 \\
\hline $\mathrm{SC}$ & 0.06 & 0.176 & $\mathrm{CE}$ & 0.05 & 0.101 & $\mathrm{~S}$ & 0.08 & 0.427 \\
\hline $\mathrm{ACD}$ & 0.05 & 0.197 & HA & 0.06 & 0.112 & $\mathrm{AO}$ & 0.06 & 0.481 \\
\hline $\mathrm{CA}$ & 0.05 & 0.216 & OT & 0.04 & 0.215 & $\mathrm{CA}$ & 0.06 & 0.560 \\
\hline SP & 0.05 & 0.245 & SP & 0.04 & 0.268 & CM & 0.06 & 0.582 \\
\hline $\mathrm{ACB}$ & 0.04 & 0.246 & ACE & 0.04 & 0.342 & $\mathrm{CB}$ & 0.06 & 0.635 \\
\hline $\mathrm{CB}$ & 0.06 & 0.287 & $\mathrm{~S}$ & 0.04 & 0.407 & $\mathrm{ZO}$ & 0.05 & 0.786 \\
\hline HA & 0.04 & 0.362 & $\mathrm{ACX}$ & 0.03 & 0.458 & & & \\
\hline TA & 0.03 & 0.388 & CS & 0.04 & 0.523 & & & \\
\hline $\mathrm{CS}$ & 0.04 & 0.434 & $\mathrm{TA}$ & 0.03 & 0.527 & & & \\
\hline $\mathrm{CM}$ & 0.04 & 0.456 & $\mathrm{ACT}$ & 0.02 & 0.555 & & & \\
\hline OT & 0.03 & 0.524 & $\mathrm{SC}$ & 0.03 & 0.594 & & & \\
\hline $\mathrm{ZO}$ & 0.03 & 0.604 & $\mathrm{ACS}$ & 0.02 & 0.605 & & & \\
\hline \multirow[t]{3}{*}{$\mathrm{S}$} & 0.02 & 0.684 & CB & 0.03 & 0.612 & & & \\
\hline & & & $\mathrm{CA}$ & 0.02 & 0.647 & & & \\
\hline & & & UNK & 0.03 & 1 & & & \\
\hline
\end{tabular}




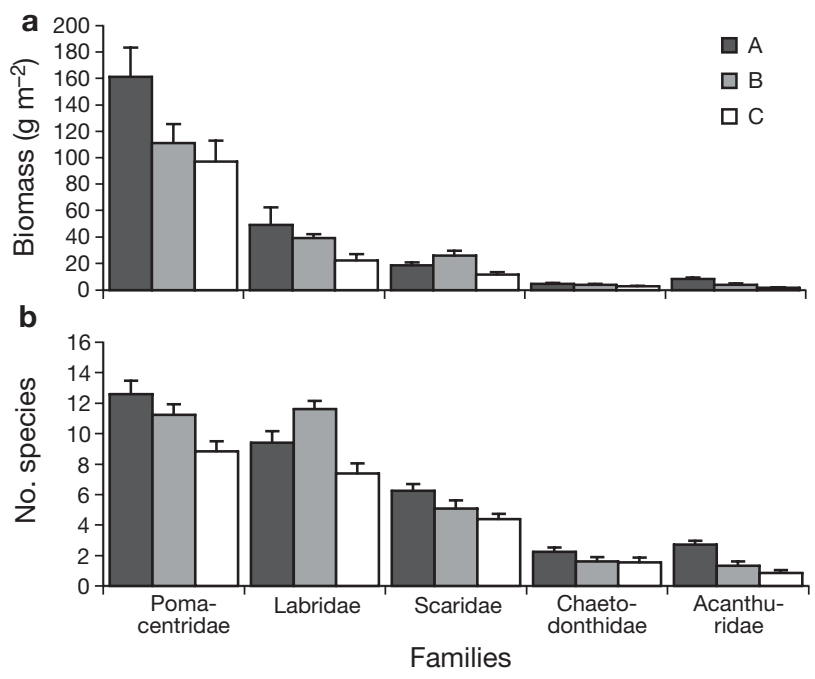

Fig. 5. (a) Biomass (g wet weight $\mathrm{m}^{-2}$ ) and (b) number of species of the 5 most important families in Reefscapes A, B and C

effect relationships are immediately obvious: zooplankton feeders negatively related to branching Acropora, branching non-Acropora and soft corals; zooplankton feeders positively related to sponges; micro-algal feeders positively related to massive non-Acropora and branching Acropora; and coral feeders positively related to massive non-Acropora.

\section{Cluster C: Low coral reefscape and associated fishes}

A low cover of coral (typically $<8 \%$ ) and medium sand cover characterised Reefscape C (Fig. 4). Of the coral present, most were non-Acropora, and soft corals, zoanthids and other invertebrates had negligible cover. Mixed algae and turf were both present in relatively high cover. Fish biomass was similar to that in Reefscape B but less than that in Reefscape A (199 \pm $28 \mathrm{~g}$ wet weight $\mathrm{m}^{-2}$; Fig. 4). A total of 119 individual fish and an average of 33 species were recorded per transect (Fig. 4). Again, Pomacentrids were the dominant family in terms of mean $( \pm \mathrm{SE})$ biomass $(97 \pm 15 \mathrm{~g}$ wet weight $\mathrm{m}^{-2}$ ) and species richness (Fig. 5). The highest contribution to the within-group similarities were made by Chrysiptera rollandi and Pomacentrus moluccensis (25.48 and $16.46 \%$, respectively), followed by Assesssor macneili (6.68\%), P. brachialis (4.91\%) and Cheilodipterus parazonatus (3.44\%) (Table 1). A total of 26 species made up $90 \%$ of within-group similarities in this reefscape.

Reefscape $\mathrm{C}$ is characterised by various substratum types, with only loosely associated fish assemblages (Fig. 6c). No association between fish and substratum was found to be statistically significant using the Monte Carlo permutation test (Table 2). Of the 3
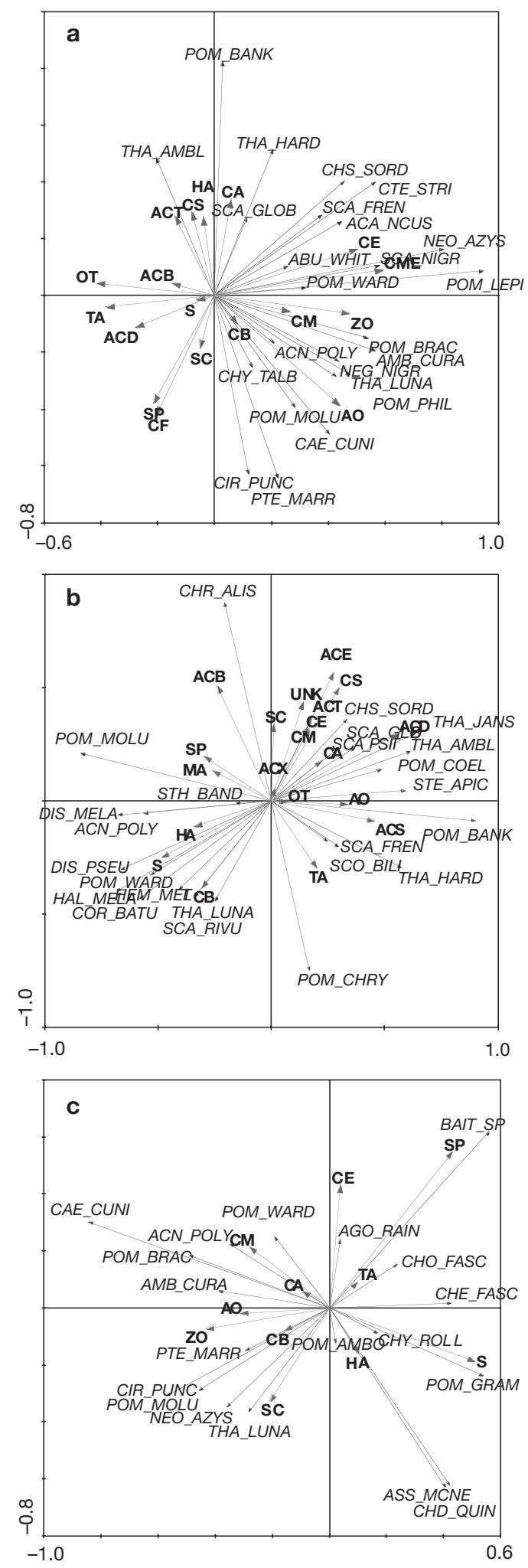

Fig. 6. Ordination diagrams of redundancy analysis in Clusters (a) A, (b) B and (c) C. Biplots of environmental variables (in bold face; see Table 2 legend) and all fish species (names are formed by the 3 first letters of the genus and the 4 first letters of the species) 
dominant fish species (Fig. 6c), the strongest associations between fish biomass and benthos were for Chrysiptera rolland with encrusting non-Acropora (CE); Pomacentrus moluccensis with Halimeda (HA) and Assesor macneili with Halimeda (HA) and sand (S).

In terms of trophic function, zooplankton feeders make the highest contribution of biomass in Reefscape $\mathrm{C}\left(99.15 \pm 19.01 \mathrm{~g}\right.$ wet weight $\mathrm{m}^{-2} ;$ Figs. 4 \& 7). This is less than half the zooplanktivore biomass of Reefscape A but $>3$ times that of Reefscape B. Plant feeders, micro- and macro-invertebrate feeders and fish feeders make very similar contributions to the mean
$( \pm \mathrm{SE})$ biomass per transect $(26.23 \pm 4.54,26.61 \pm 4.56$, $23.84 \pm 11.42$ and $18.92 \pm 10.98 \mathrm{~g}$ wet weight $\mathrm{m}^{-2}$, respectively). There were 8 statistically significant relationships between benthic attributes and trophic classes (Table 3): zooplankton feeders negatively related to massive non-Acropora, sponges, Millepora and encrusting soft corals; zooplankton feeders positively related to digitate Acropora; micro-algal feeders negatively related to encrusting and caespitose soft corals; and coral feeders positively related to foliose non-Acropora. The ecological significance of these relationships is unclear.

Table 3. Significant relationships among feeding habits and environmental variables in Reefscapes A, B and C (F: fish feeders; Ma: macro-invertebrate feeders; Mi: micro-invertebrate feeders; Z: zooplankton feeders; Hi: micro-algal feeders; Ha: macroalgal feeders; C: coral feeders). The table reports probabilities adjusted using Holm's procedure within each habitat variable (9999 permutations) (bold face: significant)

\begin{tabular}{|c|c|c|c|c|c|c|c|c|}
\hline & & F & Ma & $\mathrm{Mi}$ & $\mathrm{Z}$ & $\mathrm{Hi}$ & Ha & $\mathrm{C}$ \\
\hline \multicolumn{9}{|l|}{ Reefscape A } \\
\hline Algae other & $\begin{array}{l}\mathrm{r}(i, j) \\
\text { Prob }\end{array}$ & $\begin{array}{l}0.04979 \\
0.53040\end{array}$ & $\begin{array}{l}0.00686 \\
0.39510\end{array}$ & $\begin{array}{r}-0.01501 \\
0.29160\end{array}$ & $\begin{array}{l}0.01488 \\
0.28050\end{array}$ & $\begin{array}{r}-0.03439 \\
\mathbf{0 . 0 2 5 2 0}\end{array}$ & $\begin{array}{r}-0.01943 \\
0.21360\end{array}$ & $\begin{array}{r}-0.00502 \\
0.43170\end{array}$ \\
\hline $\begin{array}{l}\text { Encrusting } \\
\text { non-Acropora }\end{array}$ & $\begin{array}{l}\mathrm{r}(i, j) \\
\text { Prob }\end{array}$ & $\begin{array}{l}0.03449 \\
0.10890\end{array}$ & $\begin{array}{r}-0.00126 \\
0.48490\end{array}$ & $\begin{array}{l}0.02442 \\
0.17400\end{array}$ & $\begin{array}{l}0.02573 \\
0.15230\end{array}$ & $\begin{array}{r}-0.04012 \\
0.34720\end{array}$ & $\begin{array}{r}-0.07781 \\
\mathbf{0 . 0 1 5 2 0}\end{array}$ & $\begin{array}{l}0.05817 \\
0.42240\end{array}$ \\
\hline Zoanthids & $\begin{array}{l}\mathrm{r}(i, j) \\
\text { Prob }\end{array}$ & $\begin{array}{l}0.00779 \\
0.40120\end{array}$ & $\begin{array}{l}0.02918 \\
0.14310\end{array}$ & $\begin{array}{r}-0.01009 \\
0.36020\end{array}$ & $\begin{array}{l}0.00193 \\
0.47300\end{array}$ & $\begin{array}{r}-0.03618 \\
\mathbf{0 . 0 0 3 9 0}\end{array}$ & $\begin{array}{r}-0.01137 \\
0.32340\end{array}$ & $\begin{array}{r}-0.00618 \\
0.41640\end{array}$ \\
\hline Encrusting Acropora & $\begin{array}{l}\mathrm{r}(i, j) \\
\text { Prob }\end{array}$ & $\begin{array}{r}-0.04150 \\
0.04390\end{array}$ & $\begin{array}{r}-0.00268 \\
0.46010\end{array}$ & $\begin{array}{r}-0.00959 \\
0.37090\end{array}$ & $\begin{array}{r}-0.01266 \\
0.30470\end{array}$ & $\begin{array}{l}0.15340 \\
\mathbf{0 . 0 3 5 0 0}\end{array}$ & $\begin{array}{l}0.02355 \\
0.16350\end{array}$ & $\begin{array}{r}-0.02063 \\
0.22420\end{array}$ \\
\hline Macro-algae & $\begin{array}{l}\mathrm{r}(i, j) \\
\text { Prob }\end{array}$ & $\begin{array}{l}0.02846 \\
0.14150\end{array}$ & $\begin{array}{r}-0.00670 \\
0.41450\end{array}$ & $\begin{array}{r}-0.01640 \\
0.27390\end{array}$ & $\begin{array}{l}0.02778 \\
0.12980\end{array}$ & $\begin{array}{r}-0.02691 \\
\mathbf{0 . 0 1 5 2 0}\end{array}$ & $\begin{array}{r}-0.03416 \\
0.07760\end{array}$ & $\begin{array}{l}0.03206 \\
0.11300\end{array}$ \\
\hline \multicolumn{9}{|l|}{ Reefscape B } \\
\hline Massive non-Acropora & $\begin{array}{l}\mathrm{r}(i, j) \\
\text { Prob }\end{array}$ & $\begin{array}{r}-0.02224 \\
0.22720\end{array}$ & $\begin{array}{l}0.00061 \\
0.48900\end{array}$ & $\begin{array}{r}-0.06712 \\
0.11100\end{array}$ & $\begin{array}{r}-0.05934 \\
0.45900\end{array}$ & $\begin{array}{r}-0.00740 \\
0.38930\end{array}$ & $\begin{array}{l}0.08073 \\
\mathbf{0 . 0 2 6 4 0}\end{array}$ & $\begin{array}{l}0.06410 \\
\mathbf{0 . 0 4 1 2 0}\end{array}$ \\
\hline Branching Acropora & $\begin{array}{l}\mathrm{r}(i, j) \\
\text { Prob }\end{array}$ & $\begin{array}{r}-0.03157 \\
0.14310\end{array}$ & $\begin{array}{l}0.01807 \\
0.24510\end{array}$ & $\begin{array}{r}-0.05006 \\
0.45900\end{array}$ & $\begin{array}{r}-0.08160 \\
\mathbf{0 . 0 2 0 4 0}\end{array}$ & $\begin{array}{r}-0.00728 \\
0.36950\end{array}$ & $\begin{array}{l}0.10701 \\
\mathbf{0 . 0 0 7 0 0}\end{array}$ & $\begin{array}{l}0.00501 \\
0.39770\end{array}$ \\
\hline Sponges & $\begin{array}{l}\mathrm{r}(i, j) \\
\text { Prob }\end{array}$ & $\begin{array}{r}-0.05390 \\
0.45900\end{array}$ & $\begin{array}{r}-0.04492 \\
0.45900\end{array}$ & $\begin{array}{l}0.04363 \\
0.45900\end{array}$ & $\begin{array}{l}0.14567 \\
\mathbf{0 . 0 2 8 8 0}\end{array}$ & $\begin{array}{r}-0.03567 \\
0.07150\end{array}$ & $\begin{array}{r}-0.05253 \\
0.45900\end{array}$ & $\begin{array}{r}-0.05701 \\
0.45900\end{array}$ \\
\hline Branching non-Acropora & $\begin{array}{l}\mathrm{r}(i, j) \\
\text { Prob }\end{array}$ & $\begin{array}{l}0.05849 \\
0.08150\end{array}$ & $\begin{array}{l}0.05046 \\
0.03210\end{array}$ & $\begin{array}{r}-0.03305 \\
0.08880\end{array}$ & $\begin{array}{r}-0.07971 \\
\mathbf{0 . 0 3 4 1 0}\end{array}$ & $\begin{array}{l}0.02061 \\
0.21750\end{array}$ & $\begin{array}{l}0.04246 \\
0.45900\end{array}$ & $\begin{array}{r}-0.03295 \\
0.10240\end{array}$ \\
\hline Soft corals & $\begin{array}{l}\mathrm{r}(i, j) \\
\text { Prob }\end{array}$ & $\begin{array}{l}0.02042 \\
0.32090\end{array}$ & $\begin{array}{l}0.03395 \\
0.10430\end{array}$ & $\begin{array}{l}0.01598 \\
0.26690\end{array}$ & $\begin{array}{r}-0.09084 \\
\mathbf{0 . 0 0 3 6 0}\end{array}$ & $\begin{array}{r}-0.00188 \\
0.47200\end{array}$ & $\begin{array}{l}0.01490 \\
0.29130\end{array}$ & $\begin{array}{l}0.02137 \\
0.23020\end{array}$ \\
\hline \multicolumn{9}{|l|}{ Reefscape C } \\
\hline Massive non-Acropora & $\begin{array}{l}\mathrm{r}(i, j) \\
\text { Prob }\end{array}$ & $\begin{array}{l}0.04433 \\
0.11660\end{array}$ & $\begin{array}{l}0.02729 \\
0.22870\end{array}$ & $\begin{array}{l}0.05063 \\
0.07820\end{array}$ & $\begin{array}{r}-0.08892 \\
\mathbf{0 . 0 2 8 9 0}\end{array}$ & $\begin{array}{l}0.03452 \\
0.13620\end{array}$ & $\begin{array}{r}-0.00267 \\
0.48310\end{array}$ & $\begin{array}{r}-0.05851 \\
0.12460\end{array}$ \\
\hline Sponges & $\begin{array}{l}\mathrm{r}(i, j) \\
\text { Prob }\end{array}$ & $\begin{array}{l}0.04815 \\
0.10290\end{array}$ & $\begin{array}{l}0.02810 \\
0.22640\end{array}$ & $\begin{array}{l}0.05138 \\
0.07400\end{array}$ & $\begin{array}{r}-0.08876 \\
\mathbf{0 . 0 2 8 9 0}\end{array}$ & $\begin{array}{l}0.03438 \\
0.13520\end{array}$ & $\begin{array}{r}-0.00690 \\
0.43770\end{array}$ & $\begin{array}{r}-0.05822 \\
0.13330\end{array}$ \\
\hline Soft corals & $\begin{array}{l}\mathrm{r}(i, j) \\
\text { Prob }\end{array}$ & $\begin{array}{l}0.05983 \\
0.06140\end{array}$ & $\begin{array}{r}-0.01067 \\
0.39050\end{array}$ & $\begin{array}{l}0.00996 \\
0.38660\end{array}$ & $\begin{array}{l}0.05122 \\
0.06130\end{array}$ & $\begin{array}{l}0.01548 \\
0.35830\end{array}$ & $\begin{array}{r}-0.10390 \\
\mathbf{0 . 0 2 8 9 0}\end{array}$ & $\begin{array}{l}0.01193 \\
0.40510\end{array}$ \\
\hline Foliose non-Acropora & $\begin{array}{l}\mathrm{r}(i, j) \\
\text { Prob }\end{array}$ & $\begin{array}{r}-0.01235 \\
0.35390\end{array}$ & $\begin{array}{l}0.00480 \\
0.43180\end{array}$ & $\begin{array}{l}0.00541 \\
0.43350\end{array}$ & $\begin{array}{r}-0.07438 \\
0.09300\end{array}$ & $\begin{array}{l}0.01283 \\
0.41820\end{array}$ & $\begin{array}{r}-0.00172 \\
0.48860\end{array}$ & $\begin{array}{l}0.12745 \\
\mathbf{0 . 0 3 6 3 0}\end{array}$ \\
\hline Millepora & $\begin{array}{l}\mathrm{r}(i, j) \\
\text { Prob }\end{array}$ & $\begin{array}{l}0.04870 \\
0.09620\end{array}$ & $\begin{array}{l}0.02793 \\
0.22650\end{array}$ & $\begin{array}{l}0.05119 \\
0.07630\end{array}$ & $\begin{array}{r}-0.08836 \\
\mathbf{0 . 0 2 8 9 0}\end{array}$ & $\begin{array}{l}0.03426 \\
0.13650\end{array}$ & $\begin{array}{r}-0.00722 \\
0.43190\end{array}$ & $\begin{array}{r}-0.05822 \\
0.13520\end{array}$ \\
\hline Digitate Acropora & $\begin{array}{l}\mathrm{r}(i, j) \\
\text { Prob }\end{array}$ & $\begin{array}{l}0.01341 \\
0.34510\end{array}$ & $\begin{array}{r}-0.05033 \\
0.07700\end{array}$ & $\begin{array}{r}-0.06975 \\
0.11100\end{array}$ & $\begin{array}{l}0.10505 \\
\mathbf{0 . 0 2 7 0 0}\end{array}$ & $\begin{array}{r}-0.03221 \\
0.12380\end{array}$ & $\begin{array}{l}0.02305 \\
0.28500\end{array}$ & $\begin{array}{l}0.00223 \\
0.48670\end{array}$ \\
\hline Capitate soft corals & $\begin{array}{l}\mathrm{r}(i, j) \\
\text { Prob }\end{array}$ & $\begin{array}{l}0.05983 \\
0.06310\end{array}$ & $\begin{array}{r}-0.01067 \\
0.39040\end{array}$ & $\begin{array}{l}0.00996 \\
0.39010\end{array}$ & $\begin{array}{l}0.05122 \\
0.06170\end{array}$ & $\begin{array}{l}0.01548 \\
0.36250\end{array}$ & $\begin{array}{r}-0.10390 \\
\mathbf{0 . 0 2 8 9 0}\end{array}$ & $\begin{array}{l}0.01193 \\
0.40310\end{array}$ \\
\hline Encrusting soft corals & $\begin{array}{l}\mathrm{r}(i, j) \\
\text { Prob }\end{array}$ & $\begin{array}{l}0.04870 \\
0.09630\end{array}$ & $\begin{array}{l}0.02793 \\
0.22790\end{array}$ & $\begin{array}{l}0.05119 \\
0.07710\end{array}$ & $\begin{array}{r}-0.08836 \\
\mathbf{0 . 0 2 8 9 0}\end{array}$ & $\begin{array}{l}0.03426 \\
0.13970\end{array}$ & $\begin{array}{r}-0.00722 \\
0.43400\end{array}$ & $\begin{array}{r}-0.05822 \\
0.13870\end{array}$ \\
\hline
\end{tabular}




\section{DISCUSSION}

Different fish taxa or trophic groups having different ecological preferences in terms of food and shelter, and habitat partitioning among fish assemblages within a reef is common (Ohmans et al. 1997). However, at the scale of our individual sites at Davies Reef (50 $\mathrm{m}$ transects), the coupling between fish composition and benthic attributes is not tight (Figs. $6 \&$ 7). The relationships between fish species richness, biomass and trophic structure were a little clearer. The encrusting non-Acropora reefscape (A), which had the largest proportion of massive non-Acropora corals, had the highest richness in species, highest total biomass and highest biomass of zooplankton feeders. The Acropora reefscape (B), with the highest Acropora cover, lowest non-Acropora and the highest cover of turf algae, had the highest biomass of herbivorous fishes. The 'low coral' reefscape (C) had a more even distribution of trophic classes and the lowest species richness. There is no obvious explanation for the even trophic class distribution within Reefscape C, but there could be a cause and effect relationship between low coral cover and low fish species richness.

Geomorphology, depth and coral architecture also presumably act in concert to strongly partition fish assemblages. We found that mean fish species richness and biomass were higher on substrates dominated by hard corals providing vertical relief. This is not surprising given the 3D habitat structure and favourable habitats provided by high coral cover, and by branching structures in particular, for a number of demersal fish species (e.g. Bergman et al. 2000). As an example, Caribbean hard-bottom sites with a greater relative amount of 3D structure support over twice the mean species richness and diversity for fish as sand and seagrass sites, and several times greater mean fish density (Kendall et al. 2004).

The relationship between coral reef fish abundance and richness and the cover of particular corals is very complex. Other studies have found contrasting relationships between fish abundance and richness and coral cover: a strong relationship (e.g. Bell \& Galzin 1984, Bell et al. 1985, Findley \& Findley 1985, Bou-

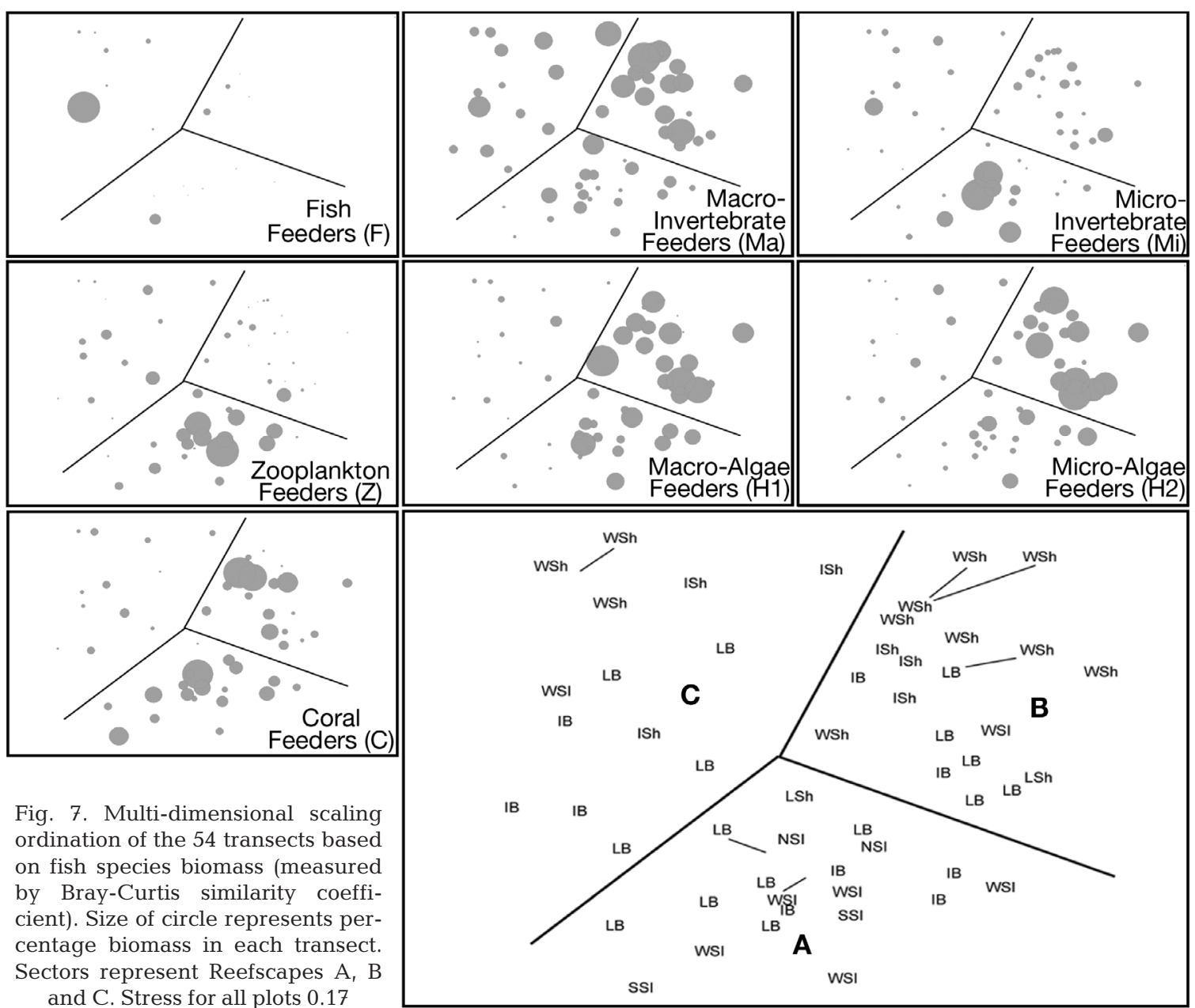


chon-Navaro \& Bouchon 1989, Nuñez-Lara \& AriasGonzález 1998) or no relationship (e.g. Wellington 1992, Sale et al. 1994, Green 1996, Ohman \& Rajasuriya 1998, Gust 2002, Lecchini et al. 2003). Lecchini et al. (2003) found that physical variables, including water depth, distance from shore and reef zone, all accounted for significant variation in the proportion of the structure of coral reef fish assemblages. This parallels the relationship that we found between fishes and reef zones, depth and aspect (Figs. 2 \& 3).

While we found significant relationships between fish assemblages and benthic habitat, we found no simple strong relationship between fish assemblage composition and our measured benthic attributes of habitats. In a general sense, multiple cues appear to be driving the distribution of fish species and trophic groups. We could discern relationships between trophic groups and reefscapes defined by grouped benthic attributes rather than a simple and strong relationship between fish assemblage composition and benthic attributes of habitats. For example, zooplankton feeders had a pronounced dominance in medium and deep reefscapes (Reefscapes A and C), while herbivores were dominant in shallow reefscapes with low cover of algae, Acropora and sand (Reefscape B). The abundance of feeders on zooplankton, plant and coral were all correlated with benthic morpho-functional groups, but the abundance of fish feeders and invertebrate feeders was not. Legendre et al. (1997) described a globally significant relationship between reef bottom materials and feeding habits. In their study, herbivorous fish were over-represented in habitats with high live corals and calcareous algae; likewise, grazers and carnivores were over-represented in habitats high in coral debris, turf and dead coral, live coral, calcareous algae and other substrates. Copepod eaters were overrepresented in habitats high in live corals and calcareous algae, whereas omnivores and piscivores did not exhibit any significant association with the substratum (Legendre et al. 1997).

Paradoxically, in our study, macro-algal feeders were under-represented in habitats that were high in 'algae, other', macro-algae and zoanthids. They were overrepresented in sites high in encrusting Acropora. This finding suggests that macro-algal feeders keep algal biomass low in their preferred, encrusting Acropora habitat. A second group, micro-algal feeders, were over-represented in sites high in massive corals, encrusting corals, and branching Acropora with abundant algal turfs. Zooplankton feeders were underrepresented in areas with high branching corals (both Acropora and non-Acropora), soft corals, encrusting soft corals, massive corals and Millepora, but overrepresented in areas high in digitate Acropora. The latter are common in windward shallow habitats exposed to currents or waves and where zooplankton washes onto the reef. Puzzlingly, coral feeders were over-represented amongst massive and foliose corals. Our study thus suggests a similar range of intuitive and non-intuitive relationships between fish assemblages and associated benthic communities as were found by Legendre et al. (1997).

Perhaps the most interesting result of this study is the capacity to extract spatial patterns of benthic life forms and depth from the fish assemblage ordinations and different analyses. Distribution patterns of fish assemblages closely followed patterns and gradients in depth, reef zone and benthic attributes. This relationship can be useful in 2 ways. First, the fish assemblage may be a useful indicator of benthic state, as well as of biotic and physical environmental gradients. Second, attributes of the benthic substratum that can rapidly be assessed may be useful proxies for predicting the type of fish community and its present state.

The multiple analysis approach used in this work was useful to extract distribution patterns of both fish and benthos. Coral reefs are extremely complex systems, and it is not an easy task to distinguish patterns and processes within them. Splitting the complex information of the system into different reefscapes and making individual analyses in each reefscape has helped to define relationships between fish and benthic assemblages. This differential analysis allows structural and functional patterns to be explored as well.

Davies Reef is a very complex system with strong, diverse and spatially structured vertical relief, geomorphology, benthos and fishes. Despite such extreme complexity, it only required 2 response variables to explain most of the variation between fish assemblages: massive encrusting corals and branching Acropora corals. These same coral categories vary systematically with changes in wave energy across reefs (Done 1982), which is, in turn, related to depth and position on the reef.

The present study stresses the importance of habitat complexity as a requirement for rich and abundant fish assemblages. It is intuitive that loss of habitat structure and complexity due to human or natural impacts could reduce reef fish richness, in species and in biomass. We found that habitat characteristics affected the evenness and richness components of diversity differently: whereas, the Acropora reefscape was associated with high fish species evenness, massive encrusting corals were associated with high fish species richness and high biomass. However, its species diversity $H^{\prime}$ was low due to low evenness brought about by substantial over-representation of zooplankton feeders, mainly Pomacentridae. 
In summary, we found that reef fishes at Davies Reef associate with each other in 3 recognisable, if overlapping, clusters. The clusters were most associated with the apparently different regimes of wave energy and turbulence characteristic of different reef zones and depths. There were some indications of fish relationships to the benthic composition and architectural complexity of the substratum. However, the latter attribute is relatively volatile, under the influences of disturbances such as the crown-of-thorns starfish, coral bleaching and storm damage. The fishes may thus cue more to the more perennial geomorphologic features such as spurs, grooves and ancient coral heads, than the more ephemeral, faster-growing elements that come and go over periods of months, years and decades.

Acknowledgements. We thank the crew of the RV 'Lady Basten' for outstanding assistance in the field. J.E.A.G. thanks CONACYT and AIMS for their hospitality and considerable logistic and financial contributions to this research, conducted during a sabbatical year.

\section{LITERATURE CITED}

Ault RT, Johnson CR (1998) Spatially and temporally predictable fish communities on coral reefs. Ecol Monogr 68(1):25-50

Bell JD, Galzin R (1984) Influence of live coral cover on coral reef fish communities. Mar Ecol Prog Ser 15:265-274

Bell JD, Craik GJS, Pollard DA, Russell BC (1985) Estimating length frequency distributions of large reef fish underwater. Coral Reefs 4:41-44

Bergman CK, Öhman CM, Svensson S (2000) Influence of habitat structure on Pomacentrus sulfureus, a western Indian Ocean reef fish. Environ Biol Fish 59:243-252

Bouchon-Navaro Y, Bouchon C (1989) Correlations between chaetodontid fishes and coral communities on the Gulf of Aqaba (Red Sea). Environ Biol Fish 25:47-60

Bradbury RH, Loya Y, Reichelt RE, Williams WT (1986) Patterns in the structural typology of benthic communities on two coral reefs on the central Great Barrier Reef. Coral Reefs 4:161-167

Caley JM, Buckley AK, Jones PG (2001) Separating ecological effects of habitat fragmentation, degradation, and loss of coral commensals. Ecology: 3435-3448

Carpenter KE, Miclat RI, Albaladejo VD, Corpuz VT (1981) The influence of substrate structure on the local abundance and diversity of Philippine reef fishes, Vol 2. In: Gomerz et al. (eds) Proc 4th Int Coral Reef Symp. Marine Sciences Center, University of the Philippines, Manila, p 497-502

Chancerelle Y (1996) Charactérisation des paysages récifaux sous-marins d'Ile de Moorea (Polynésie Française du Pacifique). PhD dissertation, EPHE, Perpignan

Clark KR (1993) Non-parametric multivariate analyses of changes in community structure. Aust J Ecol 18:117-143

Clark KR, Warwick RM (1994) Similarity-based testing for community pattern: the two-way layout with no replication. Mar Biol 118:167-176

Done TJ (1982) Patterns in the distribution of coral communities in the central Great Barrier Reef. Coral Reefs 1:95-107
Findley JS, Findley MT (1985) A search for pattern in butterfly communities. Am Nat 1126:800-816

Gladfelter WB, Gladfelter EH (1978) Fish community structure as a function of habitat structure on West Indian patch reefs. Rev Biol Trop 26(1):65-84

Gladfelter WB, Odgen JC, Gladfelter EH (1980) Similarity and diversity among coral reef fish communities: a comparison between tropical western Atlantic (Virgin Islands) and tropical central Pacific (Marshall Islands) patch reefs. Ecology 61(5):1156-1168

González-Gándara C, Membrillo-Venegas N, Nuñez-Lara E, Arias-González JE (1999) The relationship between fish and reefscapes in the Alacranes Reef, Yucatan, Mexico: a preliminary trophic functioning analysis. Vie Milieu 49(4): $275-286$

Green AL (1996) Spatial, temporal and ontogenetic patterns of habitat use by coral reef fishes (family Labridae). Mar Ecol Prog Ser 133:1-11

Grigg RW (1994) Effects of sewage discharge, fishing pressure and habitat complexity on coral reef ecosystems and reef fishes in Hawaii. Mar Ecol Prog Ser 103:25-34

Gust N (2002) Scarid biomass on the northern Great Barrier Reef: the influence of exposure, depth and substrata. Environ Biol Fish 64:353-366

Jones PG, Syms C (1998) Disturbance, habitat structure and the ecology of fishes on coral reefs. Aust J Ecol 23:287-297

Jones PG, McCormick MJ (2002) Numerical and energetic processes in the ecology of coral reef fishes. In: Sale P (ed) Coral reef fishes: dynamics and diversity in a complex ecosystem. Academic Press, Amsterdam, p 221-240

Kendall MS, Christensen JD, Caldow C, Coyne M, Jeffrey C, Monaco ME, Morrison W, Hillis-Starr Z (2004) The influence of bottom type and shelf position on biodiversity of tropical fish inside a recently enlarged marine reserve. Aquat Conserv Mar Freshw Ecosyst 14:113-132

Kulbicki M, Bargibant G, Menou JL, Mou Tham G, Thollot P, Wantiez L, Williams J (1994) Evaluation des ressources en poissons du lagon d'Ouvéa. 3ème partie: les poissons. Conv Sci Mer Biol Ma. ORSTOM, Nouméa 11:448

Lecchini D, Adjeroud M, Pratchett SM, Cadoret L, Galzin R (2003) Spatial structure of coral reef fish communities in the Ryukyu Islands, southern Japan. Oceanol Acta 26: 537-547

Legendre P, Gallagher ED (2001) Ecologically meaningful transformations for ordination of species data. Oecologica 129:271-280

Legendre P, Galzin R, Harmelin-Vivien ML (1997) Relating behavior to habitat: solutions to the fourth-corner problem. Ecology: 547-562

McCormick MJ (1994) Comparison of field methods for measuring surface topography and their associations with a tropical reef fish assemblage. Mar Ecol Prog Ser 112:87-96

Mumby PJ, Harborne RA (1999) Development of a systematic classification scheme of marine habitats to facilitate regional management and mapping of Caribbean coral reefs. Biol Conserv 88:155-163

Nuñez-Lara E, Arias-González JE (1998) The relationship between reef fish community structure and environmental variables in the southern Mexican Caribbean. J Fish Biol 53:209-221

Nuñez-Lara E, Arias-González JE, Legendre P (2005) Spatial patterns of Yucatan reef fish communities: testing models using a multi-scale survey design. J Exp Mar Biol Ecol 324:157-169

Ohmans MC, Rajasuriya A (1998) Relationship between habitat structure and fish communities on coral and sandstone reefs. Environ Biol Fish 53:19-31 
Ohmans MC, Rajasuriya A, Ólafsson E (1997) Reef fish assemblages in north western Sri Lanka: distribution patterns and influences of fishing practises. Environ Biol Fish 49: $45-61$

Page CA, Coleman G, Ninio R, Osborne K (2001) Surveys of benthic reef communities using underwater video. Longterm monitoring of the Great Barrier Reef, Standard Operational Procedure No. 7, Australian Institute of Marine Science, Townsville

Phillips JC, Kendrick GA, Lavery PS (1997) A test functional group approach to detecting shifts in macroalgal communities along a disturbance gradient. Mar Ecol Prog Ser 153:125-138

Riddle MJ, Alongi DM, Dayton PK, Hansen JA, Klumpp DW (1990) Detrital pathways in a coral reef lagoon. Mar Biol 104:109-118

Risk MJ (1972) Fish diversity on coral reef in the Virgin Islands. Atoll Res Bull 153:1-6

Editorial responsibility: Otto Kinne (Editor-in-Chief), Oldendorf/Luhe, Germany
Roberts CM, Ormond RFG (1987) Habitat complexity and coral reef fish diversity and abundance on Red Sea fringing reefs. Mar Ecol Prog Ser 41:1-8

Sale P, Guy AJ, Steel WJ (1994) Ecological structure of assemblages of coral reef fishes on isolated patch reefs. Oecologia 98:83-99

Ter Braak CJF, Smilaur F (1998) Canoco reference manual and user's guide to Canoco for Windows: software for canonical community ordination (Version 45). Microcomputer Power, Ithaca

Turner MG, Gardner RH (1991) Quantitative methods in landscape ecology: introduction. In: Turner GM, Gardner RH (eds) Quantitative methods in landscape ecology. Ecological studies 82, Springer-Verlag, Berlin, p 3-14

Wellington GM (1992) Habitat selection and juvenile persistence control the distribution of two closely related Caribbean damselfish. Oecologia 90:500-508

Submitted: February 18, 2005; Accepted: January 12, 2006 Proofs received from author(s): August 2, 2006 